\title{
Sexual maturity and reproductive period of the swimming blue crab Callinectes danae Smith, 1869 (Brachyura: Portunidae) from Guaratuba Bay, Paraná State, southern Brazil
}

Murilo Zanetti Marochi, Thaís Fernanda Moreto, Mariana Baptista Lacerda, André Trevisan and Setuko Masunari

(MZM, TFM, MBL, AT, SM) Department of Zoology, Institute of Biological Sciences, Federal University of Paraná. Centro Politécnico, Jardim das Américas, Caixa Postal 19020. CEP 81531-980 Curitiba, Paraná, Brazil. E-mail: murilomz2@hotmail.com

\begin{abstract}
This work aims to estimate the average size at the onset of morphological and physiological sexual maturity and the reproductive period of Callinectes danae. Specimens were captured from a shrimp fishing boat equipped with a trawl net from March 2009 to February 2010. After sorting, crabs were sexed, and the following morphometric dimensions were measured: carapace width $(\mathrm{CW})$, length and height of the major (MAP and HMAP), and the minor cheliped propodus (MIP and HMIP) for both sexes, and the abdominal width for females (AW). The onset of morphological maturity was estimated with the REGRANS program, in which the inflection point is calculated. The size at the onset of physiological maturity was determined by logistic regressions fitted to the relationships between the percentages of juvenile and adult individuals of each CW. A total of 893 individuals were sampled. Of these individuals, 389 were males, 472 non-ovigerous females, and 32 ovigerous females. The CW ranged from 19.81 to $117.17 \mathrm{~mm}$ for males, 19.91 to 113.11 $\mathrm{mm}$ for non-ovigerous females, and 70.55 to $88.60 \mathrm{~mm}$ for ovigerous females. Morphological sexual maturity was attained at $86.47 \mathrm{~mm} \mathrm{CW}$ (males) and 67.87 $\mathrm{mm} \mathrm{CW}$ (females). The size at the onset of physiological maturity was calculated to be $86.50 \mathrm{~mm} \mathrm{CW}$ (males) and $67.00 \mathrm{~mm} \mathrm{CW}$ (females). Due to the closeness of these values, both techniques were deemed suitable for determination of the onset of sexual maturity in $C$. danae. This species reproduces throughout the year, but reproduction is more intense during the winter. Mature males are present throughout the year. Data from this investigation will help resource managers to develop strategies that will ensure a sustainable harvest of this important species of swimming crab in southern Brazil.
\end{abstract}

Key words: Relative growth, physiological maturity, gonadal maturity

\section{INTRODUCTION}

Callinectes danae Smith, 1869 is an abundant swimming blue crab on the Brazilian coast, where it is commonly known as "siri-azul", "siri-açú", or "siri-tinga". Its distribution ranges from Florida (United States) to Rio Grande do Sul State (Brazil). The species is euryhaline. It has been recorded from brackish to hypersaline waters in estuarine bays, mangroves, sandy beaches, and the open sea, 
as well as from the intertidal to a depth of 75 meters (Melo, 1996). This species is especially numerous in Guaratuba Bay, Paraná State, where its populations occur throughout the year (Sampaio, 2009).

The species is usually captured by artisanal fishermen, but significant quantities of individuals are captured as bycatch in the shrimp drag-net fishery (Coelho and Santos, 2004). In southern and southeastern Brazil, these crabs are boiled and the muscles removed and sold as "swimming crab meat", representing a supplementary source of economic support for the families of fishermen (Garcez and Sánchez-Botero, 2005; Yomar-Hattori et al., 2006).

The estimation of the body size at which crabs attain sexual maturity is the most important parameter for the evaluation and management of natural populations with commercial value. It has been frequently used for the establishment of handling plans to regulate fishing activity (Annala et al., 1980; Corgos and Freire, 2006). Currently, the only IBAMA management action aimed at the preservation of populations of swimming crabs is the prohibition of capture of ovigerous females of any size and individuals of both sexes smaller than $12 \mathrm{~cm}$ in carapace width, including lateral spines (IBAMA, 1983).

In crustaceans, the relative growth of secondary sexual characters (usually, the width of the abdomen in females and the size of the chelipeds in males) has been studied to determine the size at which the species attains sexual maturity. Because these dimensions grow at different rates during the juvenile and adult phases, an abrupt change in these parameters has been taken to indicate the passage from the juvenile stage to the adulthood (Hartnoll, 1978).

The advantage of the analysis of external morphology as a method of determining maturity is its non-invasiveness. However, the physiological maturity of the gonads also needs to be established to determine the actual onset of sexual maturity because morphometric maturity does not always indicate functional maturity (Oh and Hartnoll, 1999). Descriptions of the stages of gonadal development are usually based on the size, position, and coloration of the gonads in males and females. However, these studies are time consuming and result in the death of the animal.

This study aims to estimate the average size at which the swimming crab $C$. danae attains sexual maturity in morphometric and functional terms. This comparative study intends to eliminate the need to perform studies on functional maturity in future research on this species. Moreover, the reproductive period was observed for the population living in Guaratuba Bay, Paraná State, southern Brazil.

\section{Material And Methods Sampling}

The swimming crabs were obtained from Guaratuba Bay (25'51'S / 48 $33^{\prime} \mathrm{W}$ and $\left.25^{\circ} 52^{\prime} \mathrm{S} / 48^{\circ} 43^{\prime} \mathrm{W}\right)$, Paraná State, southern Brazil (Fig. 1). Sampling was performed from a shrimp fishing boat equipped with a trawl net (23 mm mesh size) at four sites within Guaratuba Bay. The net was towed for 10 minutes at an average velocity of $3.5 \mathrm{~km} / \mathrm{h}$. The swimming crabs were captured bimonthly during the cold months (autumn and winter) and monthly during the warm months (spring and summer) from March 2009 to February 2010. The collected material was sorted, and the swimming crabs were preserved in a freezer prior to final handling.

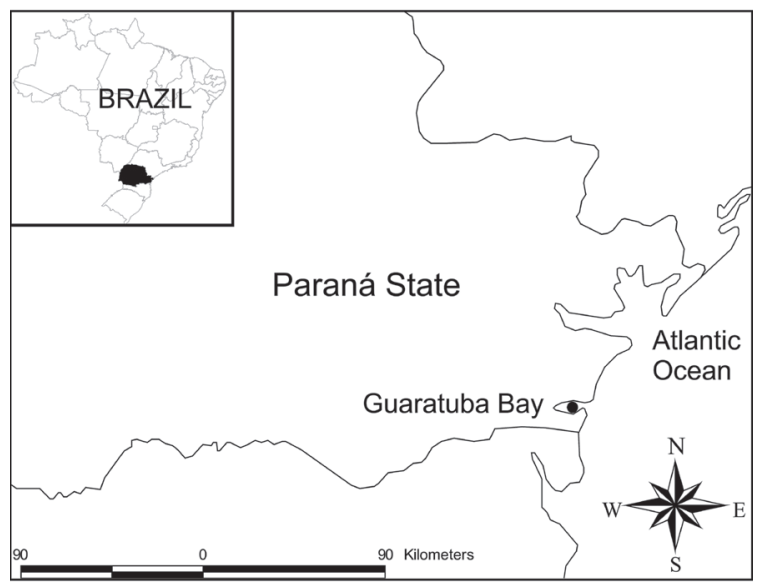

Figure 1. Location of Guaratuba Bay, Paraná State, Brazil. 


\section{Laboratory procedures}

In the laboratory, crabs were identified according to Melo (1996). Individuals of $C$. danae were measured and sexed based on the shape of the abdomen and the presence of a gonopod or gonopore.

The following body dimensions were measured to the nearest $0.01 \mathrm{~mm}$ with a digital caliper (0.01 $\mathrm{mm}$ accuracy): carapace width, including the pair of spines (CW); length and height of the propodus of the major and minor chelipeds (MAP, MIP, HMAP and HMIP) for males and females; and width of abdomen at the fourth abdominal somite in females (AW) (Fig. 2). The selection of these body dimensions was based on previous knowledge that these dimensions have biological meaning relative to the passage from the juvenile stage to the adulthood (Hartnoll, 1974; 1978).
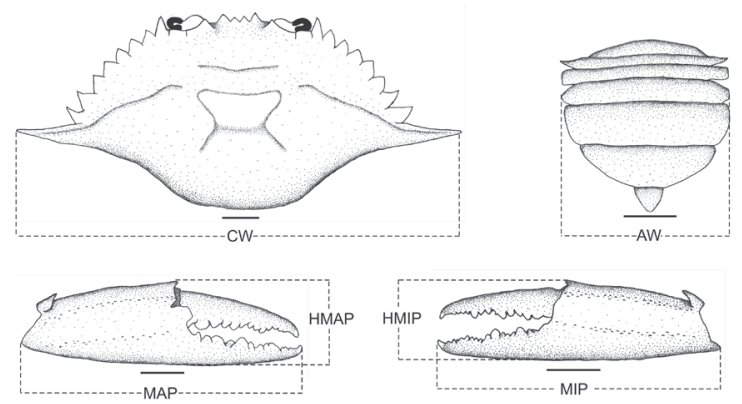

Figure 2. Callinectes danae. Body dimensions measured. CW: carapace width, AW: abdominal width at the fourth abdominal somite (only for females), MAP: length of the major cheliped propodus, HMAP: height of the major cheliped, MIP: length of the minor cheliped propodus, HMIP: height of the minor cheliped. Scale bar $=1 \mathrm{~cm}$.

\section{Gonadal maturity and reproductive period}

The stages of the gonadal development of males and females were recognized based on the color and on the relative size of the gonads in relation to the hepatopancreas and vas deferens in dissected specimens. The gonads were classified into four categories for males and six for females according to the classification adapted from Costa and Negreiros-Fransozo (1998) (Tab. 1).

The reproductive period was determined based on the relative frequency of ovigerous females and on the individuals of both sexes with gonads in an advanced stage of development.
The average size at functional maturity was determined by interpolation of the equation obtained from a logistic regression analysis of the maturation condition of each individual ( 0 = immature and $1=$ mature $)$ as a function of the CW dispersion points according to the methodological procedures proposed by Pagano and Gauvreau (2006). This average size indicates that $50 \%$ of the individuals in the population showed evidence of gonadal maturation (a stage equal to or greater than DE for males and females according to Tab. 1).

Table 1. Callinectes danae. Description of the stages of gonadal development for males and females (adapted from Costa and Negreiros-Fransozo, 1998).

\begin{tabular}{|c|c|c|}
\hline & Stage & Description \\
\hline & & Males \\
\hline IM & Immature & Gonads not differentiated \\
\hline RU & Rudimentary & $\begin{array}{l}\text { Vas deferens close to stomach; gonads } \\
\text { transparent and pale yellow }\end{array}$ \\
\hline DE & Developing & $\begin{array}{l}\text { Gonads visible in the anterolateral } \\
\text { region; vas deferens can be divided } \\
\text { into two areas; ratio of gonads to } \\
\text { hepatopancreas approximately } 1: 4\end{array}$ \\
\hline \multirow[t]{2}{*}{ DD } & Developed & $\begin{array}{l}\text { Vas deferens with three distinct areas; } \\
\text { ratio of gonads to hepatopancreas } \\
\text { approximately } 1: 2\end{array}$ \\
\hline & & Females \\
\hline IM & Immature & Gonads not differentiated \\
\hline RU & Rudimentary & $\begin{array}{l}\text { Gonad filamentous with pale yellow } \\
\text { coloration }\end{array}$ \\
\hline $\mathrm{DE}$ & Developing & $\begin{array}{l}\text { Gonads yellowish; ratio of gonads to } \\
\text { hepatopancreas approximately } 1: 8\end{array}$ \\
\hline IN & Intermediary & $\begin{array}{l}\text { Gonads bright orange; ratio of gonads } \\
\text { to hepatopancreas approximately } 1: 2 \text {. } \\
\text { Ovary with lobes }\end{array}$ \\
\hline $\mathrm{AD}$ & Advanced & $\begin{array}{l}\text { Gonads bright orange with well } \\
\text { developed lobes }\end{array}$ \\
\hline OV & Ovigerous & $\begin{array}{l}\text { Females with external egg masses } \\
\text { attached to pleopods }\end{array}$ \\
\hline
\end{tabular}

\section{Relative growth and morphological maturity}

The description of relative growth and the calculation of the average size at the onset of morphological sexual maturity in $C$. danae were performed with the allometric equation $Y$ $=a X^{b}$. This equation was transformed $(\log Y=$ $\log a+b \log X)$. The carapace width (CW) was used as the independent variable $(X)$, and the remaining dimensions were used as dependent variables (Y) (Huxley, 1950).

The determination of the inflection point that segregated juveniles and adults in 
the graph of the relationship between CW and cheliped dimensions (for males) and in the graph of the relationship between CW and AW (for females) was performed with the aid of the REGRANS program (Pezzuto, 1993).

The allometric coefficient of the equation (b) that shows the similarity between the data on juveniles and adults was evaluated by Student's $t$ test to verify whether the allometric growth was positive or negative (values statistically greater than or less than 1.00 , respectively) or isometric (values statistically near 1.00).
The slope of the lines and the intersections between the lines for juveniles and adults were tested with the aid of an analysis of covariance (ANCOVA), using a 95\% confidence interval (Sokal and Rohlf, 1979).

\section{Results}

In all, $893 C$. danae were obtained during the sampling period. Of these individuals, 389 were males, 472 non-ovigerous females and 32 ovigerous females. The male $\mathrm{CW}$ ranged from
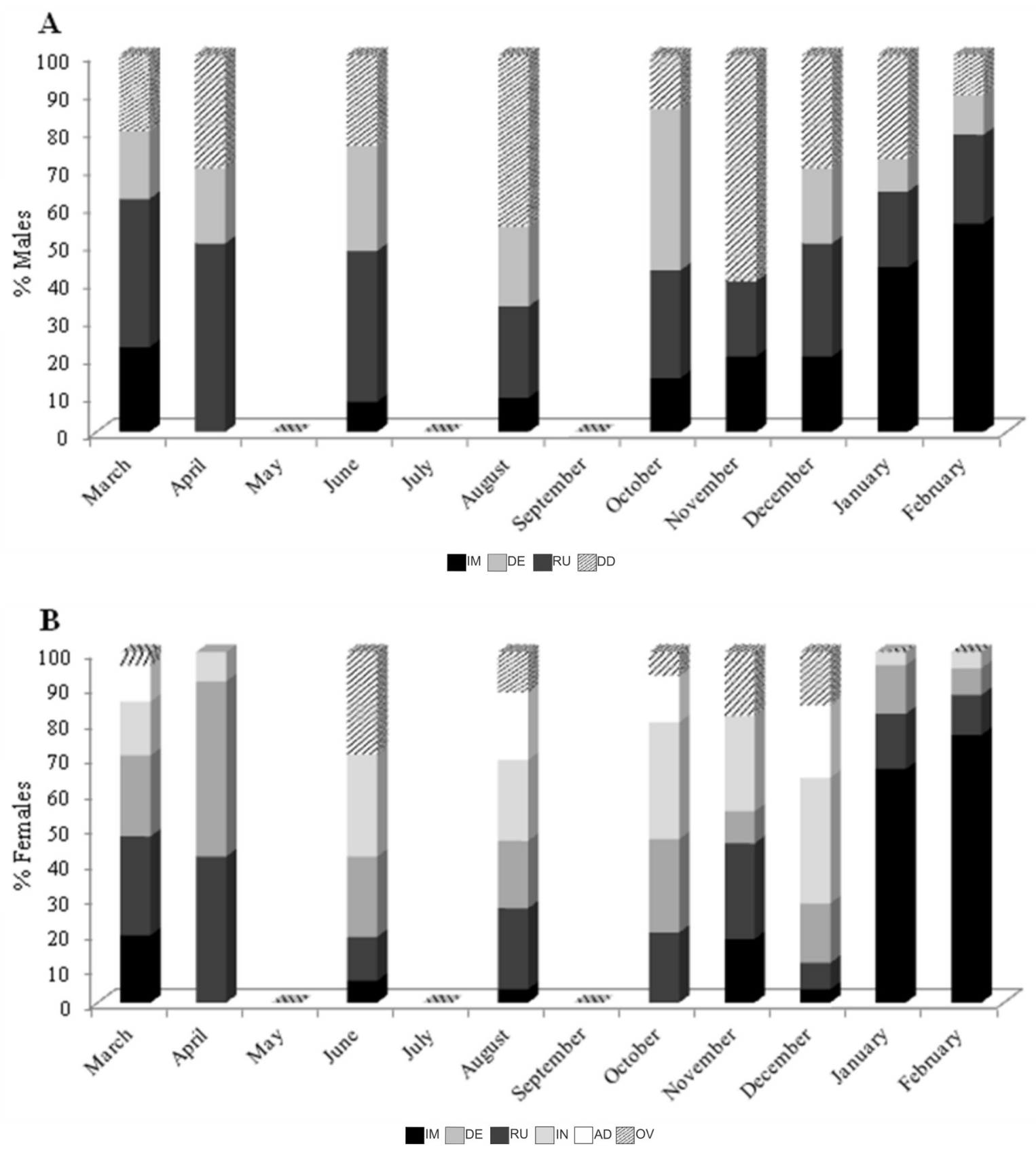

Figure 3. Callinectes danae. Temporal variation in the percentage of swimming crabs in different stages of gonadal development for males (A) and females (B). IM: Immature, RU: Rudimentary, DE: Developing, IN: Intermediary, AD: Advanced, DD: Developed, OV: Ovigerous. 
19.8 to $117.1 \mathrm{~mm}$, the non-ovigerous female CW from 19.9 to $113.1 \mathrm{~mm}$ and the ovigerous female CW from 70.5 to $88.6 \mathrm{~mm}$.

\section{Gonadal maturity and reproductive period}

Male $C$. danae showed the four gonadal developmental stages in all months except in November, when the DE stage was missing (Fig. 3). In contrast, the gonadal stage composition of the females was highly variable, but the IN stage was strongly predominant during the summer months (January and February). Ovigerous females were recorded in all sampling months, except in April; however, advanced stages (IN and AD) occurred throughout the year (Fig. 3).

The average $\mathrm{CW}$ at the onset of physiological maturity in $C$. danae was estimated as $86.5 \mathrm{~mm} \mathrm{CW}$ for males and 67.0 $\mathrm{mm} \mathrm{CW}$ for females (Fig. 4).

\section{Relative growth and morphological maturity}

All analyzed dimensions showed positive allometry in their relative growth. The male chelipeds and female abdomen increased in size at a higher velocity than the carapace throughout the lifespan (before and after puberty). Equivalently, the slopes of the allometric regression lines were statistically greater than 1.00 according to a Student t test.

However, the dimensions that were most closely related to morphological sexual maturity among males were MAP and MIP.
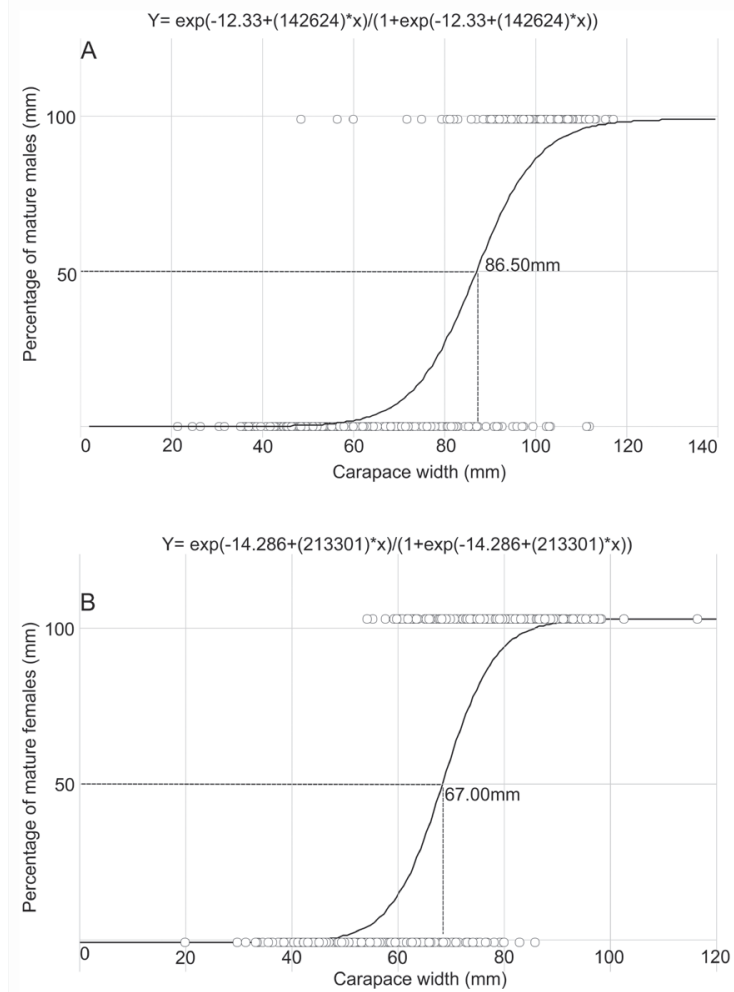

Figure 4. Callinectes danae. Logistic regressions (solid lines) fitted to the percentage of the presence (value of 1) and the absence (value of 0 ) of mature individuals (gonads in IM, RU, DE, IN, AD, OV or DD stages), at a given carapace length to establish the average $\mathrm{CW}$ at which the species attains physiological maturity for males (A) and females (B).

This result shows that the length of both major and minor chelipeds is more important than their height as an indicator of morphological sexual maturity in males. The scatterplots showed inflection points at $88.4 \mathrm{~mm} \mathrm{CW}$ for both dimensions (Fig. 5).

Table 2. Callinectes danae. Formula and statistics for linear regressions of major chela propodus length on carapace width (MAP $\mathrm{x}$ $\mathrm{CW}$ ), height of major chela on carapace width (HMAP $\mathrm{x} C W)$, minor chela length on carapace width (MIP $\mathrm{x}$ CW), height of minor chela on carapace width (HMIP x CW), for males and females, and abdominal width on carapace width (AW $\mathrm{x} C W$ ) for females. Regressions were calculated for data subdivided into two sets, at the left $(<\mathrm{X})$ and at the right $(\geq \mathrm{X})$ of the inflection point $(\mathrm{X})$ in the scatterplots, yielding separate regressions. $\mathrm{JM}=$ juvenile male, $\mathrm{AM}=$ adult male, $\mathrm{JF}=$ juvenile female, $\mathrm{AF}=$ adult female, $\mathrm{N}=$ sample size; $\mathrm{r}^{2}=$ coefficient of determination; $\mathrm{T}=$ Student $\mathrm{t}$-test value $(\mathrm{b}=1)$.

\begin{tabular}{|c|c|c|c|c|c|c|c|}
\hline Dimension & $\begin{array}{c}\text { Demographic } \\
\text { category }\end{array}$ & $\mathbf{N}$ & $\begin{array}{l}\text { Inflection point } \\
(\mathrm{CW} \mathrm{mm})\end{array}$ & $\begin{array}{c}\text { Formula } \\
\log Y=\log a+b \log \mathrm{X}\end{array}$ & $\mathbf{r}^{2}$ & $\mathbf{T}(\mathbf{b}=\mathbf{1})$ & Allometry \\
\hline \multirow{2}{*}{ MAP } & $\mathrm{JM}$ & 132 & \multirow{2}{*}{88.47} & $\log C W=\log -0.5280+1.10 \log M A P$ & 0.97 & 73.56 & + \\
\hline & $\mathrm{AM}$ & 115 & & $\log C W=\log -0.7877+1.25 \log M A P$ & 0.98 & 17.06 & + \\
\hline \multirow{2}{*}{ HMAP } & $\mathrm{JM}$ & 71 & \multirow{2}{*}{62.26} & $\log C W=\log -1.2330+1.16 \log \mathrm{HMAP}$ & 0.93 & 20.65 & + \\
\hline & $\mathrm{JM}$ & 174 & & $\log C W=\log -1.6601+1.39 \log \mathrm{HMAP}$ & 0.94 & 37.29 & + \\
\hline \multirow{2}{*}{ MIP } & $\mathrm{JM}$ & 130 & \multirow{2}{*}{88.47} & $\log C W=\log -0.8323+1.26 \log \mathrm{MIP}$ & 0.96 & 86.61 & + \\
\hline & $\mathrm{AM}$ & 115 & & $\log C W=\log -0.6139+1.14 \log \mathrm{MIP}$ & 0.94 & 48.23 & + \\
\hline \multirow{2}{*}{ HMIP } & $\mathrm{JM}$ & 53 & \multirow{2}{*}{54.91} & $\log C W=\log -1.4397+1.27 \log \mathrm{HMIP}$ & 0.97 & 63.17 & + \\
\hline & AM & 191 & & $\log C W=\log -1.4935+1.31 \log \mathrm{HMIP}$ & 0.92 & 17.03 & + \\
\hline \multirow{2}{*}{ AW } & JF & 253 & \multirow{2}{*}{67.87} & $\log C W=\log -1.5433+1.48 \log A W$ & 0.86 & 83.39 & + \\
\hline & $\mathrm{AF}$ & 187 & & $\log C W=\log -1.5214+1.51 \log A W$ & 0.62 & 36.47 & + \\
\hline
\end{tabular}



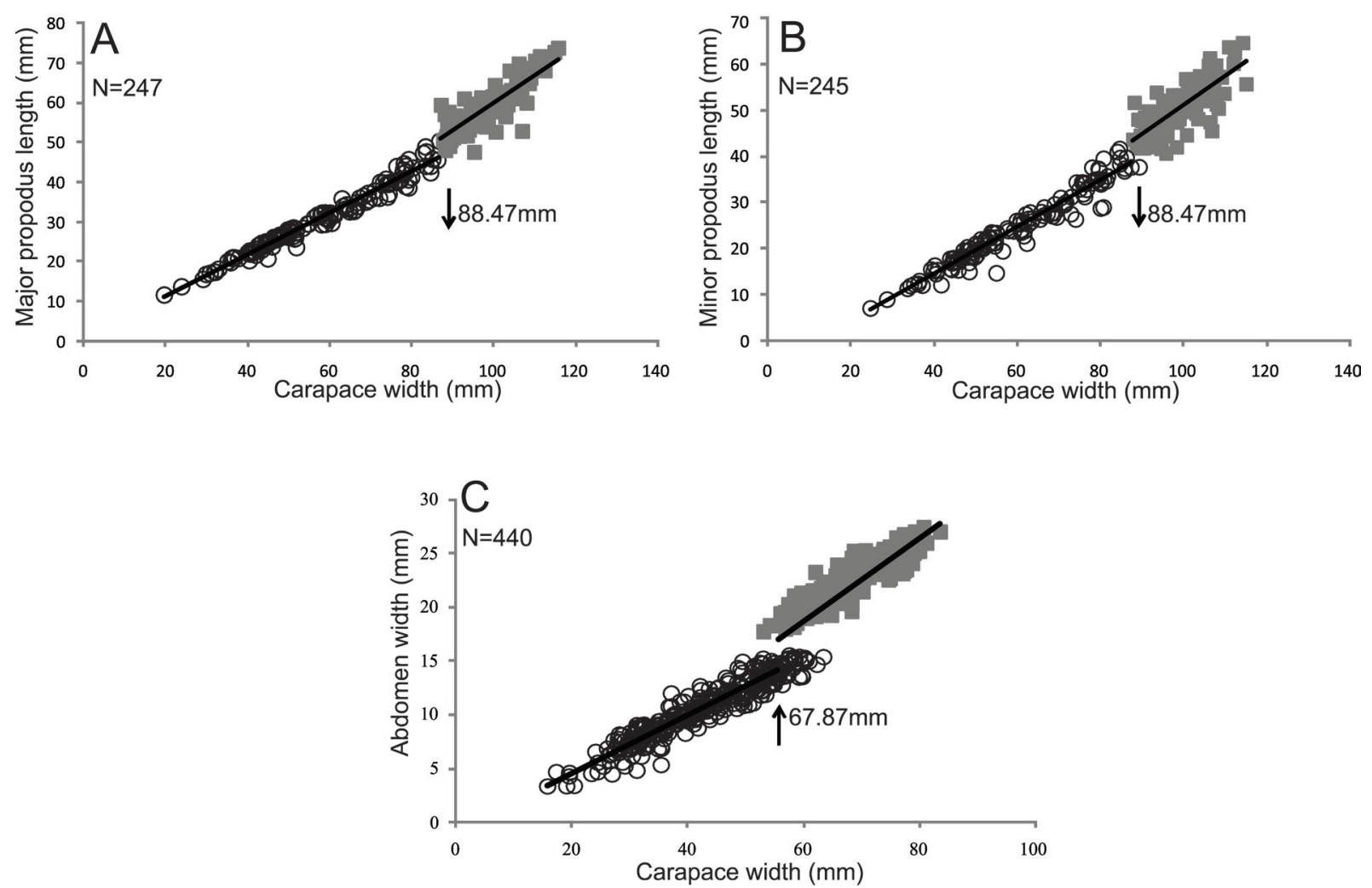

Figure 5. Callinectes danae. Scatterplots of CW and propodus dimensions (males) and of CW and AW (females). The subsets at left refer to juvenile data and at right to adult data. A: CW x MAP (males). B: CW x MIP (males). C: CW x AW (females). CW: carapace width; MAP: Major cheliped propodus length. MIP: Minor cheliped propodus length; AW: Abdominal width. Dark squares: adults; dark circles: juveniles.

Similarly, the abdomen was a good indicator of maturity in females (Tab. 2). The value of the inflection point obtained in the scatterplot (67.8 mm CW) (Fig. 5) was very close to the $\mathrm{CW}$ of the smallest ovigerous female $(70.5 \mathrm{~mm})$ in the samples.

An ANCOVA results (Table 3) showed that there were significant differences between the intercepts (a) and slopes (b) of the straight lines for juveniles and adults in most relationships evaluated $(\mathrm{p}<0.05)$ except for

Table 3. Callinectes danae. Comparisons of the straight line slopes and intercepts for juveniles and adults of both sexes based on a covariance analysis (ANCOVA). CW= carapace width; $\mathrm{MAP}=$ Major cheliped propodus length; HMAP= Height of the major cheliped; $\mathrm{MIP}=$ Minor cheliped propodus length; $\mathrm{HMIP}=$ Height of the minor cheliped; $\mathrm{AW}=$ Abdominal width; $\mathrm{M}=$ Male; $\mathrm{F}=$ Female.

\begin{tabular}{|c|c|c|c|c|c|}
\hline Sex & Relation & $\mathbf{F}(\mathbf{a})$ & $\mathbf{F}(\mathbf{b})$ & $\alpha(a)$ & $\alpha(\mathbf{b})$ \\
\hline \multirow{4}{*}{ M } & CW x MAP & 13.95 & 173.41 & 0.0005 & $<0.0001$ \\
\hline & CW x MIP & 1.47 & 129.45 & 0.2237 & $<0.0001$ \\
\hline & CW x HMAP & 99.65 & 8.37 & $<0.0001$ & 0.0044 \\
\hline & CW x HMIP & 102.45 & 1.48 & $<0.0001$ & 0.2221 \\
\hline $\mathrm{F}$ & CW x AW & 0.36 & 143.96 & 0.56 & $<0.0001$ \\
\hline
\end{tabular}

CW $x$ AW. The latter two parameters exhibited straight lines with similar intercepts $(p>0.05)$ but with different slopes $(\mathrm{p}<0.05)$.

\section{Discussion}

The maximum $\mathrm{CW}$ in $C$. danae varies substantially among different populations. There is strong evidence that abiotic variables related to the local climate have the strongest influence on this parameter, as previously stated in the literature (Wenner et al., 1974; Annala et al., 1980; Araújo et al., 2012). Except for the population from Pontal do Sul, PR recorded by Baptista-Metri et al. (2005), more southerly localities show larger values of the maximum CW in this species for both sexes (Tab. 4). A difference of more than 20\% occurs between populations from northern (Pernambuco State) and southern Brazil (Santa Catarina State) (Tab. 4). The $\mathrm{CW}_{50}$ also showed the same tendency, most likely linked to local factors such as temperature, salinity, and food availability (Wenner et al., 1974; Annala et al., 1980; Araújo et al., 2012). 
Table 4. Callinectes danae. Maximum CW and $\mathrm{CW}_{50 \%}$ values for males and females for populations from different localities in Brazil, ordered by increasing latitude.

\begin{tabular}{|c|c|c|c|c|c|}
\hline \multirow[t]{2}{*}{ Locality } & \multicolumn{2}{|c|}{$\mathrm{CW} \max (\mathbf{m m})$} & \multicolumn{2}{|c|}{$\mathrm{CW}_{50 \%}(\mathrm{~mm})$} & \multirow[t]{2}{*}{ Reference } \\
\hline & Male & Female & Male & Female & \\
\hline Itamaracá, PE $\left(07^{\circ} 34^{\prime} \mathrm{S}, 34^{\circ} 04^{\prime} \mathrm{W}\right)$ & 95.60 & 82.30 & 70.50 & 59.50 & Araújo et al. (2012) \\
\hline Carrapicho River, Itamaracá, PE ( $\left.07^{\circ} 39^{\prime} S, 34^{\circ} 51^{\prime} \mathrm{W}\right)$ & - & 83.48 & - & 61.59 & Barreto et al. (2006) \\
\hline Botafogo River, Itamaracá, PE ( $\left.07^{\circ} 43^{\prime} \mathrm{S}, 34^{\circ} 53^{\prime} \mathrm{W}\right)$ & - & 101.00 & - & 63.58 & Barreto et al. (2006) \\
\hline 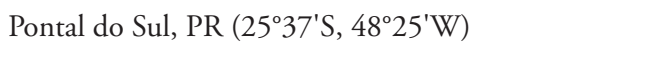 & 93.20 & 86.00 & 60.50 & 52.70 & Baptista-Metri et al. (2005) \\
\hline Guaratuba Bay, PR (2551'S, 48³3'W) & 117.00 & 113.00 & 86.50 & 67.00 & Present study \\
\hline Florianópolis, SC (27³0'S, $\left.48^{\circ} 00^{\prime} \mathrm{W}\right)$ & 130.50 & 110.50 & 94.00 & 84.00 & Branco and Masunari (2000) \\
\hline Florianópolis, SC(2734'S, 48³0'W) & - & - & 99.00 & 89.00 & Branco and Thives (1991) \\
\hline
\end{tabular}

The sexual dimorphism in size (CW in males larger than in females) recorded in the present study is typical for brachyuran crabs (Tessier, 1960; Hartnoll 1974, 1985) and is also in accordance with previous studies on populations of $C$. danae in Brazil (Branco and Thives, 1991; Costa and Negreiros-Fransozo, 1998; Branco and Masunari, 2000; BaptistaMetri et al., 2005; Araújo et al., 2012). This dimorphism has been explained by assuming that females obtain a selective advantage by investing energy in large egg masses, whereas large males enjoy a reproductive advantage over small ones (Hartnoll, 1982; 1985; Van Engel, 1985). Consequently, males attain the onset of morphological sexual maturity at a larger CW than females, with a difference of approximately $10 \mathrm{~mm}$ (Tab. 4).

In the present study, the CW at which crabs attain the onset of physiological maturity was very close to the morphological value for both sexes $(86.5$ and $88.4 \mathrm{~mm} \mathrm{CW}$, respectively, for males; 67.0 and $67.8 \mathrm{~mm}$ $\mathrm{CW}$, respectively, for females). Apparently, the males first become physiologically mature and then show the external morphological changes that mark the transition from the juvenile stage to adulthood. The size of the smallest ovigerous female in the samples $(70.55 \mathrm{~mm}$ CW) was consistent with the value of the onset of sexual maturity calculated for the females. Therefore, for the Guaratuba Bay population of $C$. danae, a simple measurement of the CW would serve to evaluate the size of sexually mature individuals. This result means that no dissection of the swimming crabs would be necessary.
The similarity of the CW values at both types of maturity found in the present study contrasts with the results of previous studies of $C$. danae. For example, Barreto et al. (2006) recorded substantially different sizes at sexual and morphological maturity for females, and Araújo et al. (2012) described similar results for both sexes in populations from northeastern Brazil. Among other portunid species, both sexes of Necora puber (Linnaeus, 1767) (González-Gurriarán and Freire, 1994) and males of Arenaeus cribrarius (Lamarck, 1818) (Pinheiro and Fransozo, 1998) displayed asynchronous maturities. These disparities may result from restricted sampling areas and different methods used to capture crabs. Most ovigerous females of $C$. danae, for example, migrate from estuarine waters to the saltier open sea to spawn, whereas the males stay within the bays (Branco and Masunari, 2000; Sampaio, 2009). Therefore, samples collected only within a bay or estuarine areas would result in an underestimate of the range of CWs in ovigerous females.

The minimum CW allowed by IBAMA (1983) for harvesting $(12.0 \mathrm{~cm})$ appears to be based on another swimming blue crab species, Callinectes sapidus Rathbun, 1896. This species is sympatric with $C$. danae and attains a greater CW (16.2 cm, according to Rodrigues and D'Incao, 2008). Thus, the minimum CW for $C$. danae can be lower than $12.0 \mathrm{~cm}$, but the fisherman must be skilled to distinguish between the two species of swimming crabs.

The positive allometric growth recorded in the dimensions analyzed in the present study 
indicates that they have biological meaning, especially in terms of reproductive activities. This result is consistent with previous studies of brachyuran crabs (Tessier, 1960; Giménez and Acevedo, 1982; Pinheiro and Fransozo, 1993), and it indicates more rapid growth of secondary sexual characters in $C$. danae in both juveniles and adults. Likewise, it was observed that the degree of allometry was always higher in adulthood. This result suggests that although the analyzed dimensions grew more rapidly than the $\mathrm{CW}$ in the juvenile stages, the difference in growth rates intensified after the puberty molt or the onset of morphological sexual maturity.

The present study showed that the best dimension for estimating the onset of morphological sexual maturity for males was the major and minor cheliped propodus length (MAP and MIP). The major and minor cheliped propodus height did not appear to be linked with this onset. The coincidence of the inflection values for the major and minor cheliped propodus reinforces this finding. As mentioned above, these differential growth rates have been explained by assuming different evolutionary pressures on males and females during reproduction (Hartnoll, 1982; Tsuchida and Fujikura, 2000).

Usually, the reproductive period has been identified by the presence and frequency of ovigerous females. The low frequencies of ovigerous females collected in the present study were, most likely, a consequence of the regular migration of females into the open sea (Sampaio, 2009). It is certain that these rare ovigerous females were captured during their journey toward coastal waters. In this context, females with gonads in the AD stage were the best indicator of the reproductive period in the estuarine waters.

The continuous presence of crabs of both sexes in advanced stages of gonadal development in the present study indicates that $C$. danae can be considered to have continuous reproduction, according to Pinheiro and Fransozo (2002). This type of reproduction has also been reported from other populations from Paraná State (BaptistaMetri et al., 2005) and from the coast of São
Paulo State (Costa and Negreiros-Fransozo, 1998; Chacur and Negreiros-Fransozo, 2001). However, two peaks of reproductive intensity have been observed in populations from the coast of São Paulo (Pita et al., 1985; Chacur et al., 2000; Pinheiro and Fransozo, 2002), Paraná (Baptista-Metri et al., 2005) and Santa Catarina (Branco and Masunari, 2000). Although a peak corresponding to ovigerous females is visible in the frequency distribution (Fig. 3), it is virtually impossible to conclude that $C$. danae of Guaratuba Bay shows a higher reproductive intensity in the winter because no collections were performed in the adjacent sea, to which these females regularly migrate.

These disparities in the reproductive periods of various populations indicate that each locality is influenced by a particular set of abiotic variables and that $C$. danae shows high phenotypic plasticity.

ACKNOWLeDgments - All sampling in this study complies with the current laws of Paraná State and the Brazilian Federal Government and was conducted with the permission of the Brazilian Institute of Environment and Renewable Natural Resources - IBAMA - of Paraná State (Authorization \#169-DIFAP/IBAMA). We also thank the National Council for Scientific and Technological Development (CNPq), Coordination of Improvement of Higher Education (CAPES) of the Brazilian Ministry of Science and Technology for scholarships awarded to the authors and American Journal Experts for English revision. This is Contribution No. 1873 of the Department of Zoology, Federal University of Paraná.

\section{REFERENCES}

Annala, J.H.; Mckoy, J.L.; Booth, J.D. and Pike, R.B. 1980. Size at the onset of sexual maturity in female Jasus edwardsii (Decapoda: Palinuridae) in the New Zealand. Journal of Marine and Freshwater Research, 14(13): 217-221.

Araújo, M.S.L.C.; Negromonte, A.O.; Barreto, A.V. and Castiglioni, D. 2012. Sexual maturity of the swimming crab Callinectes danae (Crustacea: Portunidae) at Santa Cruz Channel, a tropical coastal environment. Journal of the Marine Biological Association of the United Kingdom, 92(2): 287-293.

Baptista-Metri, C.; Pinheiro, M.A.A.; Blankensteyn, A. and Borzone, C.A. 2005. Biologia populacional e reprodutiva de Callinectes danae Smith (Crustacea: Portunidae), no Balneário Shangri-lá, Pontal do Paraná (PR), Brasil. Revista Brasileira de Zoologia, 22: 446-453. 
Barreto, A.V.; Batista-Leite, L.M.A. and Aguiar, M.C.A. 2006. Maturidade sexual das fêmeas de Callinectes danae (Crustacea, Decapoda, Portunidae) nos estuários dos rios Botafogo e Carrapicho, Itamaracá, PE, Brasil. Iheringia, Série Zoologia, 96(2): 141-146.

Branco, J.O. and Thives, A. 1991. Relação peso/largura, fator de condição e tamanho de primeira maturação de Callinectes danae Smith, 1869 (Crustacea: Portunidae) no manguezal do Itacorubi, SC, Brasil. Brazilian Archives of Biology and Technology, 34: 415-424.

Branco, J.O. and Masunari, S. 2000. Reproductive ecology of the blue crab Callinectes danae Smith, 1869 in the Conceição Lagoon system, Santa Catarina Isle, Brazil. Revista Brasileira de Zoologia, 60: 17-27.

Chacur, M.M.; Mansur, C.B. and Negreiros-Fransozo, M.L. 2000. Distributional patterns, seasonal abundance and moult cycle of Callinectes danae Smith, 1869 in the Ubatuba region, Brazil. Nauplius, 8(2): 215-226.

Chacur, M.M. and Negreiros-Fransozo, M.L. 2001. Spatial and seasonal distributions of Callinectes danae (Decapoda, Portunidae) in Ubatuba Bay, São Paulo, Brazil. Journal of Crustacean Biology, 21(2): 414-425.

Coelho, P.A. and Santos, M.C.F. 2004. Siris do estuário do rio Una, São José da Coroa Grande, Pernambuco - Brasil (Crustacea, Decapoda, Portunidae). Boletim Técnico Científico CEPENE, 12(1): 187-194.

Corgos, A. and Freire, J. 2006. Morphometric and gonad maturity in the spider crab: a comparison of methods for estimating size at maturity in species with determinate growth. Journal of Marine Science, 63: 851-859.

Costa, T.M. and Negreiros-Fransozo, M.L. 1998. The reproductive cycle of Callinectes danae Smith, 1869 (Decapoda, Portunidae) in the Ubatuba Region, Brazil. Crustaceana, 71(6): 615-627.

Garcez, D.S. and Sánchez-Botero, J.I. 2005. Comunidades de pescadores artesanais no Estado do Rio Grande do Sul, Brasil. Atlântica, 27(1): 17-29.

Giménez, E. and Acevedo, M. 1982. Relaciones morfométricas y talla de primera maduración del cangrejo de tierra Cardisoma guanhumi Latreille em La Ciénega de Zapata. Revista Cubana de Investigaciones Pesqueras, 7: 18-37.

González-Gurriarán, E. and Freire, J. 1994. Sexual maturity in the velvet swimming crab Necora puber (Brachyura, Portunidae): morphometric and reproductive analysis. Journal of Marine Science, 51: 133-145.

Hartnoll, R.G. 1974. Variation in growth patterns between some secondary sexual characters in crabs. Crustaceana, 27: 131-136.

Hartnoll, R.G. 1978. The determination of relative growth in Crustacea. Crustaceana, 34: 281-293.

Hartnoll, R.G. 1982. Growth. p. 11-196. In: D.E. Bliss (ed.). The Biology of Crustacea: Embryology, Morphology and Genetics. New York, Academic Press.
Hartnoll, R.G. 1985. Growth, sexual maturity and reproductive output. p. 15-17. In: A. M. Wenner (ed.). Factors in Adult Growth.

Huxley, J.S. 1950. Relative growth and form transformation. Proceedings of the Royal Society London. 137(B): 465-469.

IBAMA (Instituto Brasileiro do Meio Ambiente e dos Recursos Naturais e Renováveis). 1983. Portaria SUDEPE no N-24, de 26 de julho de 1983. Disponível em: <http://www.pesca.sp.gov.br/leg n24.php>. Acesso em: abril de 2012.

Melo, G.A.S. 1996. Manual de Identificação dos Brachyura (caranguejos e siris) do litoral brasileiro. São Paulo, Plêiade, 603p.

Oh, C.W. and Hartnoll, R.G. 1999. Size at sexual maturity, reproductive output, and seasonal reproduction of Philocheras trispinosus (Decapoda) in Port Erin Bay, Isle of Man. Journal of Crustacean Biology, 19(2): 252-259.

Pagano, M. and Gauvreau, K. 2006. Princípios de Bioestatística. Thompson, São Paulo, Brasil. 506p.

Pezzuto, P.R. 1993. REGRANS: a "basic" program for an extensive analysis of relative growth. Atlantica, 15: 91-105.

Pinheiro, M.A.A. and Fransozo, A. 1993. Relative growth of the speckled swimming crab Arenaeus cribrarius (Lamarck, 1818) (Brachyura, Portunidae), near Ubatuba, State of Sáo Paulo, Brazil. Crustaceana, 65: 365-376.

Pinheiro, M.A.A. and Fransozo, A. 1998. Sexual maturity of the speckled swimming crab Arenaeus cribrarius (Lamarck, 1818) (Decapoda, Brachyura, Portunidae), in the Ubatuba littoral, São Paulo State, Brazil. Crustaceana, 71: 434-452.

Pinheiro, M.A.A and Fransozo, A. 2002. Reproduction of the speckled swimming crab Arenaeus cribrarius (Brachyura: Portunidae) on the Brazilian coast near $23^{\circ} 30^{\prime}$ S. Journal of Crustacean Biology, 22(2): 416428.

Pita, J.B.; Rodrigues, E. S.; Graça-Lopes, R. and Coelho, J.A.P. 1985. Observações bioecológicas sobre o siri Callinectes danae Smith, 1869 (Crustacea, Portunidae), no Complexo Baía-Estuário de Santos, Brasil). Boletim do Instituto de Pesca, 12(4): 35-43.

Rodrigues, M.A. and D'Incao, F. 2008. Comparação do crescimento entre Callinectes sapidus (Crustacea, Decapoda, Portunidae) coletados em campo e mantidos em condiçóes controladas. Iheringia, Série Zoologia, 98(3): 372-378.

Sampaio, S.R. 2009. Distribuição dos siris e biologia reprodutiva de Callinectes danae Smith, 1869 (Decapoda, Portunidae) na Baía de Guaratuba e área costeira adjacente, Paraná, Brasil. Universidade Federal do Paraná, Ciências Biológicas (Zoologia), Master Dissertation. 82p. [Unpublished].

Sokal, R.R. and Rohlf, J.F. 1979. Biometry. 3rd ed. W. H. Freeman and Co., New York.

Tessier, G. 1960. Relative growth. 473-536p. In: Waterman T.H (ed.). The Physiology of Crustacea. New York: Academic Press.

Tsuchida, S. and Fujikura, K. 2000. Heterochely, relative growth and gonopod morphology in the bythograeid crab, Austinograea williamsi (Decapoda, Brachyura). Journal of Crustacean Biology, 20: $407-$ 414. 
Van Engel, W.A. 1985. The blue crab and its fishery in Chesapeake Bay. I. Reproduction, early development, growth, and migration. Commercial Fisheries Review, 20: 6-17.

Wenner, A.M.; Fusaro, C. and Oaten, A. 1974. Size at onset of sexual maturity and growth rate in crustacean populations. Canadian Journal of Zoology, 52: 1095-1106.

Yomar-Hattori, G.; Sampaio-Sant'anna, B. and Pinheiro, M.A.A. 2006. Meat yield of Callinectes bocourti A. Milne-Edwards, 1879 (Crustacea, Portunidae) in Iguape, São Paulo, Brazil. Investigaciones Marinas, 34(2): 231-236. 